\title{
DESKRIPSI JUMLAH LIMFOSIT ABSOLUT PADA HIPERURISEMIA
}

\author{
Meri Meri ${ }^{1 *} \cdot$ Yane Liswanti ${ }^{2} \cdot$ Hemarisa Nurizkillah ${ }^{3}$ \\ 1Prodi D-III Teknologi Laboratorium Medis, STIKes Bakti Tunas Husada Tasikmalaya, \\ Jawa Barat, Indonesia \\ e-Mail : meri@stikes-bth.ac.id
}

\begin{abstract}
Hyperuricemia is a condition of increased levels of uric acid in the blood. Physiological conditions, uric acid has the form of a solute. The crystals will form if the levels are above $6.8 \mathrm{mg} / \mathrm{dL}$ or at the saturation point. It will settle in various tissues, including the kidneys and joints. Hyperuricemia can cause various types of diseases such as hypertension, kidney disorders, arterosklesrosis, cardiovascular, gout and others. Crystals monosodium urat cancause innate and adaptive immune responses. Innate immune response is played by macrophages for phagocytic and produce pro-inflammatory cytokines and can stimulate lymphocyte activation. Its presence can be determined by counting the absolute lymphocyte count, thus giving an indication of the prognosis of the disease due to hyperuricemia. The purpose of this research is to describe the absolute lymphocyte count in hyperuricemia. This type of research is descriptive cross sectional study approach. The number of research subjects was 30 participants taken by purposive sampling with criteria for men aged 18-65 years, hyperuricemia, fasting 10-12 hours, no obesity, no infection, not children and not elderly. The results showed that $6.7 \%$ (2 people) had an increased absolute lymphocyte count, and $93.3 \%$ (28 people) had a normal absolute lymphocyte count. In conclusion, absolute lymphocyte counts can describe the prognosis due to hyperuricemia, as a result of the adaptive immune response.
\end{abstract}

Keywords : description, absolute lymphocyte count, hyperuricemia

\begin{abstract}
Abstrak
Hiperurisemia adalah kondisi meningkatnya kadar asam urat dalam darah. Pada keadaan fisiologis, asam urat memiliki bentuk berupa zat terlalut, namun bila kadarnya berada diatas $6,8 \mathrm{mg} / \mathrm{dL}$ atau sudah berada dalam titik jenuh, akan mengalami pembentukan kristal dan mengendap diberbagai jaringan, termasuk ginjal dan sendi. Hiperurisemia dapat menimbulkan berbagai jenis penyakit seperti hipertensi, gangguan ginjal, arterosklesrosis, kardiovaskular dan lain-lain. Asam urat tersebut dapat membentuk kristal kemudian menimbulkan respon imun innate dan juga adaptive. Respon imun innate diperankan oleh makrofag untuk proses fagositosis sehingga menghasilkan sitokin proinflamasi dan dapat merangsang aktivasi limfosit. Keberadaannya dapat ditentukan dengan menghitung jumlah limfosit absolut sebagai indikasi adanya prognosis penyakit akibat hiperurisemia. Tujuan penelitian yaitu mendeskripsikan jumlah limfosit absolut pada hiperurisemia. Jenis penelitian adalah deskriptif dengan pendekatan crosssectional study. Jumlah subjek peneltian adalah 30 partisipan yang diambil secara purposive sampling dengan kriteria laki-laki berusia 18-65 tahun, hiperursemia, berpuasa 10-12 jam, tidak obesitas dan tidak infeksi. Hasil menunjukan bahwa sebesar $6,7 \%$ (2 orang) memiliki jumlah limfosit absolut yang meningkat, dan sebesar 93,3\% (28 orang) memiliki JolMedLabS. 2020;1(1):11-22


jumlah limfosit absolut normal. Kesimpulan, jumlah limfosit absolut dapat menggambarkan prognosis akibat hiperurisemia, sebagai hasil respon imun adaptive.

Kata Kunci : deskripsi, jumlah limfosit absolut, hiperurisemia

\section{PENDAHULUAN}

Asam urat, merupakan produk atau hasil akhir dari pemecahan metabolisme nukleotida purin (yaitu dari guanin dan adenin), dengan rumus molekul $\mathrm{C}_{5} \mathrm{H}_{4} \mathrm{~N}_{4} \mathrm{O}_{3}, 7,9$-dihydro-1 $\mathrm{H}$-purine-2,6,8(3H)-trion dan memiliki berat molekul 168 Da (El \& Tallima, 2017).

Asam urat memiliki peran fisiologis yang sangat menguntungkan yaitu sebagai antioksidan (Liu et al., 2018; El \& Tallima, 2017). Namun, bila kadarnya berlebihan dapat menimbulkan berbagai penyakit seperti hipertensi (Stewart, Langlois, \& Noone, 2019), gangguan fungsi ginjal (Frezzatti, Alves, Alponti, \& Silveira, 2018), artherosklerosis (Maiuolo, Oppedisano, Gratteri, Muscoli, \& Mollace, 2016; Maden, Pamuk, \& Pamuk, 2017), gout (Yuan et al., 2018) diabetes mellitus tipe 2 (Luo et al., 2016), penyakit kardiovaskular(Su, Hong, Zhao, Sun, \& Li, 2016) dan lain-lain.

Kadar asam urat yang meningkat dalam darah dinamakan sebagai hiperurisemia. Kondisi hiperurisemia bagi laki-laki, yaitu di atas $7,0 \mathrm{mg} / \mathrm{dL}$ (Andres, J.A. Bernal, \& Pascual, 2017), sedangkan bagi perempuan, yaitu di atas $6,0 \mathrm{mg} / \mathrm{dL}$ (Maiuolo et al., 2016;Su et al., 2016). Asam urat yang meningkat tersebut dapat menimbulkan respon imun karena asam urat dianggap sebagai molekul "sinyal bahaya" atau damage-associated molecular pattern (DAMP) (Braga et al., 2017; Ghaemi-oskouie \& Shi, 2011). Jenis DAMP lainnya, selain asam urat adalah ATP, heat-shock proteins, high-mobility group box 1 (HMGB1), DNA, reactive oxygen intermediates, dan heparin sulfat (Ramadan, Land, \& Paczesny, 2017).

Asam urat dalam darah memiliki wujud berupa zat terlarut. Namun, asam urat juga dapat membentuk kristal. Asam urat akan membentuk kristal (kristal monosodium urat) jika kadarnya dalam darah sudah mengalami titik jenuh 
JolMedLabS

Meri Meri, dkk | 13

(Martillo, Nazzal, \& Crittenden, 2014), yaitu di atas 6,8 mg/dL (Ghaemi-oskouie \& Shi, 2011). Kristal inilah yang dapat menimbulkan pemumpukan pada jaringan, kemudian menyebabkan inflamasi (Ghaemi-oskouie \& Shi, 2011) terutama pada ginjal dapat menimbulkan Chronic Kidney Disease (CKD) dan juga pada sendi (seperti Gout, dan Arthritis) (Duan et al., 2019;Rock, Kataoka, \& Lai, 2013).

Asam urat dalam bentuk terlarut (soluble) maupun kristal dapat mengaktifkan NLRP3 inflamasome, kemudian mengeluarkan sitokin proinflamasi seperti interleukin-1 betha (IL-1B) (Schett, Schauer, Hoffmann, \& Herrmann, 2015; Braga et al., 2017), Tumor Necrosis Factor-alfa (TNF-a) (Busso \& So, 2010) dan IL-6 (Di et al., 2017). Sitokin proinflamasi tersebut dapat menginduksi atau mempengaruhi respon dari limfosit (Moro-garcía et al., 2018).

Limfosit merupakan sel imun adaptive. Sel ini berperan penting dalam pemusnahan antigen secara spesifik. Respon imun seluler ini diawali dengan aktivasi sel $\mathrm{T}$ naif menjadi sel $\mathrm{T}$ efektor, dengan cara berproliferasi dan berdiferensiasi (Abbas \& Licthman, 2015). Peranannya dalam darah dapat dilihat dengan mengukur jumlah sel dan aktivitas selnya (Castro-junior et al., 2012). Dalam darah orang dewasa, secara normal memiliki jumlah limfosit absolut sebanyak $1,0-4,8 \times 10^{3} / \mu \mathrm{L}$. Jumlah limfosit absolut ini dapat memberikan gambaran prognosis suatu penyakit. Jumlah limfosit absolut yang rendah, menandakan adanya defisiensi imun (Pamely, 2013) dan indikator atau prognosis yang buruk (Tojek et al., 2020) sedangkan, jumlah limfosit absolut yang tinggi memberikan gambaran penyakit yang persisten (Yuan et al., 2018)

Pada penelitian Yuan et al., 2018,memberikan gambaran bahwa jumlah limfosit (terutama subset limfosit TH17 dan TH2) mengalami peningkatan pada penderita Gout. Peningkatan kedua subset limfosit tersebut, menandakan indikasi penting adanya serangan Gout. Subset limfosit TH17 dapat berperan dalam persistensi suatu penyakit. Pada penelitian Ruggiero et al., (2006) menunjukan bahwa jumlah leukosit pada hiperurisemia mengalami kenaikan dan secara signifikan berhubungan dengan kejadian hiperurisemia. Pada 
penelitian Chang et al., (2017) memberikan informasi bahwa pada laki-laki pekerja pabrik baja di Cina yang mengalami hiperurisemia memiliki jumlah limfosit absolut yang meningkat, disertai oleh adanya paparan timbal. Pada penelitian Su et al., (2016) menunjukan indikator hematologi salah satunya menggambarkan jumlah leukosit yang meningkat pada orang dewasa yang menderita hiperurisemia, namun tidak menggambarkan jumlah limfosit absolut secara khusus.

Berbeda dengan penelitian sebelumnya, maka diperlukan informasi mengenai deskripsi jumlah limfosit absolut pada laki-laki dewasa penderita hiperurisemia secara umum, bukan pada pekerja berat seperti pekerja pabrik baja, dan bukan pada penderita gout.

\section{BAHAN DAN METODE}

Subjek penelitian yang diperiksa adalah 30 orang partisipan yang diambil secara purposive sampling, pada bulan Maret-Juni 2019. Berdasarkan kriteria inklusi : berjenis kelamin laki-laki berusia 18-65 tahun, berpuasa 10-12 jam dan mengalami hiperurisemia. Kriteria ekslusi : obesitas (pengukuran IMT), mengalami infeksi, dan usia anak-anak. Alat pendukung : Hematoanalyzer MINDRAY BC 5300 dan Fotometer TC 3300. Bahan: darah vena sebanyak $3 \mathrm{ml}$, dengan pembagian whole blood untuk pemeriksaan jumlah limfosit absolut dan serum untuk pemeriksaan asam urat. Reagen yang dipakai berasal dari PT. Akurat Intan Madya (Asam Urat) disertai serum kontrol. Pengukuran sampel dilakukan setelah dilakukan quality control baik untuk pemeriksaan jumlah limfosit absolut maupun untuk pemeriksaan asam urat.

Jenis penelitian adalah deskriptif dengan pendekatan metode cross sectionalstudy, yang dimulai dengan pemberian informed consent yang telah mendapatkan izin kode etik dari Komite Etik STIKes Bakti Tunas Husada Tasikmalaya. Kemudian, dilanjutkan dengan pemeriksaan laboratorium di Rumah Sakit Jasa Kartini untuk pemeriksaan jumlah limfosit absolut dan di 
JolMedLabS

Meri Meri, dkk | 15

Laboratorium Prodi D3 Teknologi Laboratorium Medis STIKes Bakti Tunas Husada Tasikmalaya untuk pemeriksaan kadar asam urat.

Data dianalisis menggunakan statistik deskriptif menggunakan SPSS versi 25.0. Hasil analisis dipresentasikan dalam bentuk gambar diagram dan tabel berupa nilai frekuensi, mean dan simpangan deviasi.

\section{HASIL}

Hasil penelitian dapat dilihat pada tabel 1. yang berisi karakteristik subjek penelitian. Jumlah subjek penelitian adalah sebanyak 30 orang laki-laki dengan usia 23-59 tahun, menjalani puasa selama 10-12 jam, tidak mengalami obesitas dengan melihat nilai indeks masa tubuh (IMT), tidak mengalami infeksi, bukan usia anak-anak dan bersedia mengisi informed consent. Jumlah limfosit absolut pada hiperurisemia dapat dilihat pada gambar 1.

Tabel1.Deskripsi Karakteristik Partisipan

\begin{tabular}{lccc}
\hline \multicolumn{1}{c}{ Uraian Karakteristik } & N Statistik & Mean & SD \\
\hline Usia (tahun) & 30 & 42,6 & 8,9 \\
\hline Tinggi Badan (cm) & 30 & 167,3 & 5,6 \\
\hline Berat Badan (kg) & 30 & 66,9 & 10,3 \\
\hline Indeks Masa Tubuh (IMT) & 30 & 23,8 & 3 \\
\hline Kadar Asam Urat (mg/dL) & 30 & 8,9 & 1,05 \\
\hline $\begin{array}{l}\text { Jumlah Limfosit Absolut (x10 } \\
\text { sel/ } \mu \text { L) }\end{array}$ & 30 & 2,68 & 0,81 \\
\hline
\end{tabular}

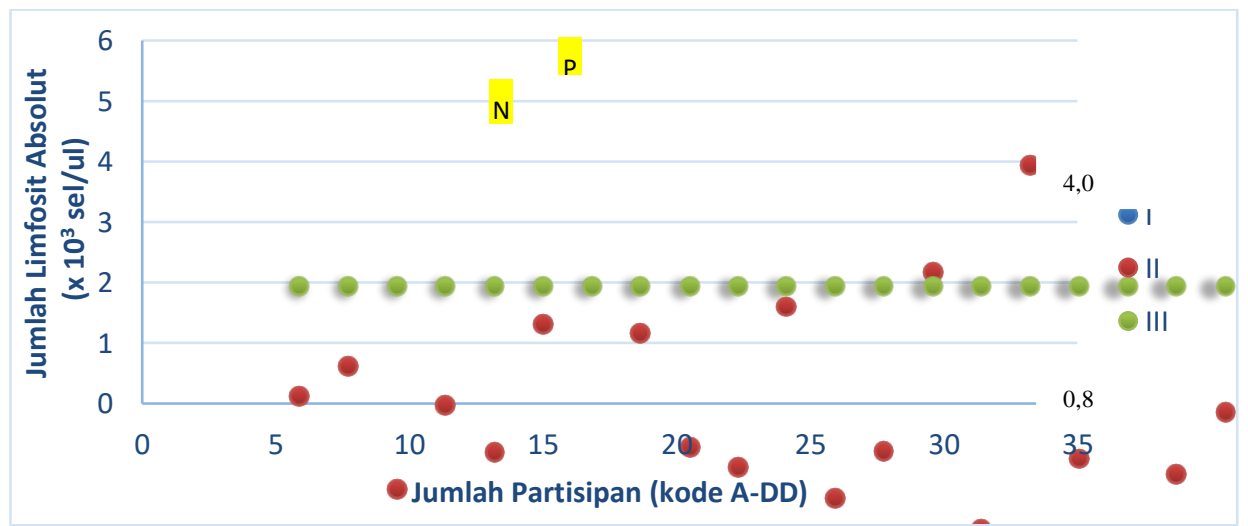

Gambar1.Deskripsi Jumlah Limfosit Absolut (l= Jumlah Limfosit Absolut normal pada batas bawah; II= Jumlah Limfosit Absolut Sampel; III= Jumlah Limfosit Absolut Normalpada Batas Atas) 


\section{DISKUSI}

Hasil penelitian terhadap 30 orang partisipan, bukan pekerja berat, sebagian besar memiliki jumlah limfosit absolut yang normal yaitu sebanyak 93,3\% (28 orang), pada rentang $0,8-4,0 \times 10^{3} \mathrm{sel} / \mu \mathrm{L}$ (RS Jasa Kartini). Hal ini terjadi karena jumlah tersebut belum menimbulkan respon imun secara kronik, sehingga jumlah limfosit absolut tidak mengalami peningkatan. Sebagian kecil, yaitu $6,7 \%$ (2 orang) memiliki jumlah limfosit yang meningkat (kode $\mathrm{N}$ dan $\mathrm{P}$ ). Hal ini bisa terjadi karena adanya aktivasi limfosit oleh sitokin-sitokin yang dihasilkan dalam merespon adanya kristal asam urat (Tojek et al., 2020). Jumlah limfosit absolut yang meningkat menandakan adanya inflamasi secara kronik akibat hiperurisemia.

Asam urat yang mengalami pengkristalan dapat menimbulkan pengendapan pada jaringan dan dapat menimbulkan inflamasi yang berkepanjangan sehingga diperlukan respon imun adaptif dalam pemusnahannya, seperti yang terjadi pada kasus gout, mengalami peningkatan jumlah limfosit absolut (Yuan et al., 2018).

Semua partisipan yang mengalami hiperurisemia, memiliki hasil jumlah limfosit absolut yang dominannya normal. Namun, ada 2 orang yang meningkat. Jumlah limfosit absolut yang meningkat menandakan ada respon imun adaptif terhadap kejenuhan asam urat dalam darah. Namun, pada proses pembentukan kristal akibat kejenuhan tersebut bisa terjadi oleh karena beberapa faktor. Keadaan tersebut bisa dipengaruhi oleh kondisi $\mathrm{pH}$, temperatur, komponen tulang rawan, tekanan mekanis, faktor synovial dan faktor serum (Martillo et al., 2014). Selain itu, kadar garam, getaran dan besarnya molekul dapat mempercepat pembentukan asam urat menjadi kristal monosodium urat (Firestein, Budd, Gabriel, McInnes, \& O’Dell, 2013). Pada kondisi asam, maka akan makin cepat terjadi pembentukan kristal. Keadaan suhu rendah juga mempercepat timbulnya kristalisasi asam urat. Kandungan synovial seperti 
JolMedLabS

Meri Meri, dkk | 17

fosfatidilkolindan kondroitin sulfat berkontribusi dalam mempercepat laju pembentukan kristal asam urat (Martillo et al., 2014). Suhu dan temperatur yang lebih rendah adalah fakta bahwa pengendapan kristal menjadi lebih mudah. Hal tersebut lebih sering terkena serangan gout (Firestein et al., 2013).

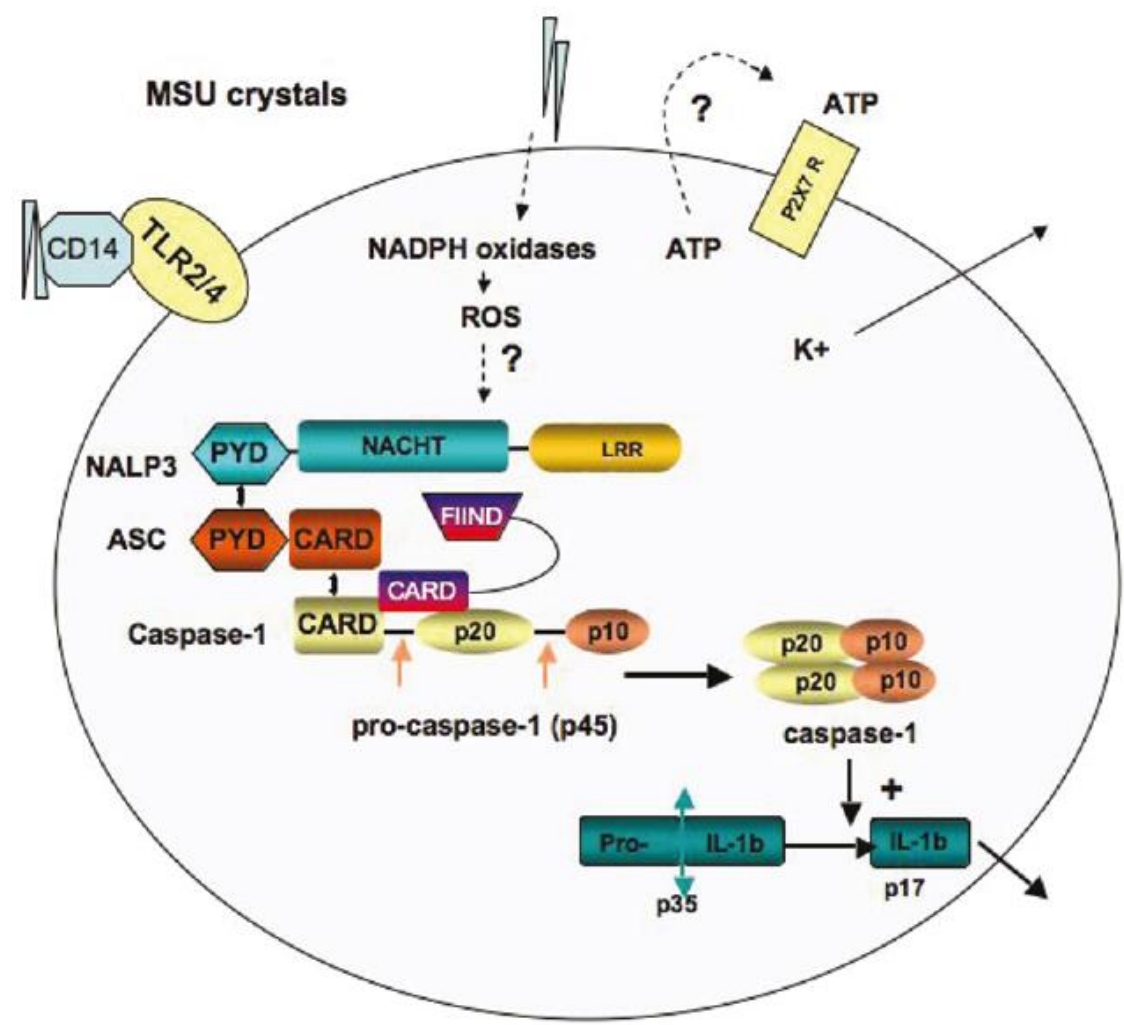

Gambar 2. Produksi Sitokin Proinflamasi (IL-1B) yang diinduksi oleh Kristal Asam Urat (El \& Tallima, 2017;Busso \& So, 2010)

Mekanisme inflamasi yang diakibatkan hiperurisemia adalah mulai dari pembentukan asam urat terlarut menjadi kristal asam urat. Asam urat pada mulanya berbentuk terlarut. Jika melebihi batas solubilitasnya (Schett et al., 2015), kemungkinan akan mengalami pengendapan dalam bentuk kristal. Pengendapan kristal asam urat akan mengaktivasi sel makrofag setempat. Makrofag merespon kristal asam urat melalui pattern recognition receptors (PRR), yaitu oleh NLRP3 inflamasome. NLRP3 adalah subunit sensor spesifik terdiri dari protein adaptor apoptosis-associated speck-like protein (ASC) berisi caspase-recruitment domain (CARD) dan pro enzim caspase-1 inaktif. NLRP3 
yang aktif akan mengaktifkan ASC dan kaspase 1 kemudian berinteraksi dengan pyridin domain (PYD) serta CARD sehingga dapat mematurasi pro-IL1B menjadi IL-1B (gambar 2) dalam bentuk aktif secara biologis (Abbas \& Licthman, 2015; El \& Tallima, 2017). Selain melalui NLRP3, IL-1B juga dapat dihasilkan dari proses pengenalan kristal asam urat oleh TLR2/4 dengan mekanisme mengaktifkan NFkb melalui aktivasi adaptor MyD88 (Mayer-barber \& Yan, 2016).

IL-B, bersama dengan aktivasi komplemen (menghasilkan C5a), akan menyebabkan neutrofil mengalami infiltrasi ke tempat pengendapan kristal. Neutrofil memfagosit kristal asam urat yang dilewatinya dan melepaskan asam arakidonat prostaglandin-D2 (PGE2) dan leucotrin-B4 (LTB4)(Martillo et al., 2014). Mediator inflamasi PGE2 dan LTB4 akan memicu vasodilatasi dan berfungsi sebagai kemotaksis sel neutrofil (gambar 3), monosit dan eosinofil(Busso \& So, 2010). Masuknya neutrofil dalam jumlah besar ke dalam jaringan adalah tanda adanya inflamasi secara akut. Inflamasi dapat menjadi konik jika sudah didominasi pengerahan oleh monosit dan limfosit(Wahid \& Miskad, 2016).

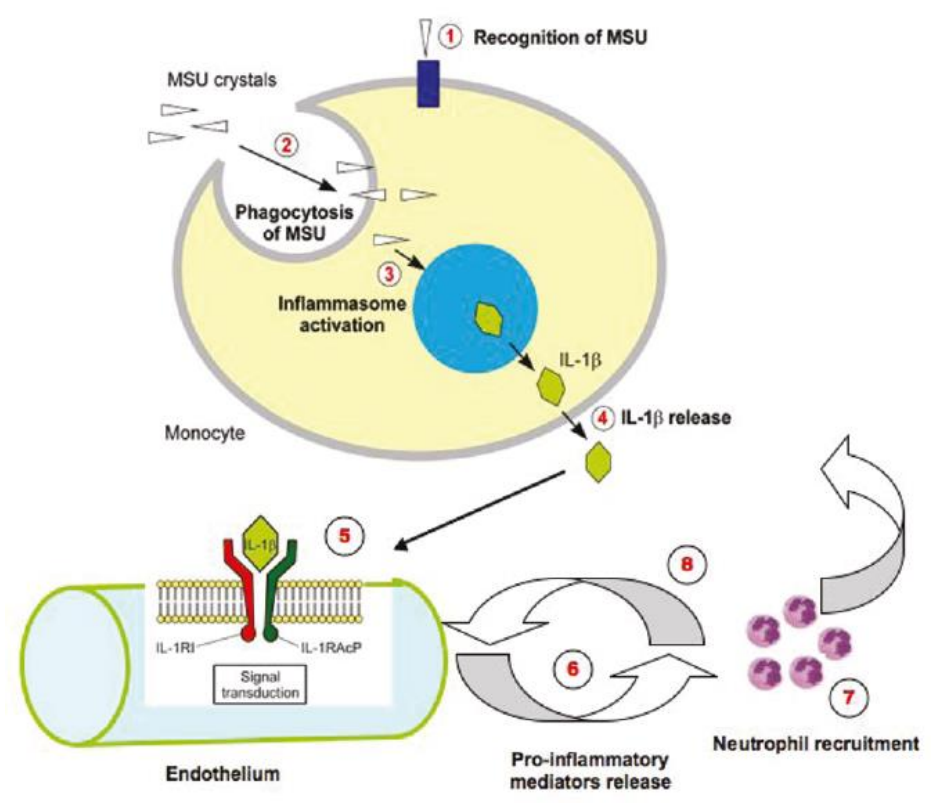

Gambar 3.Proses Pelepasan Mediator Pro-inflamasi (Mayer-barber \& Yan, 2016) 
IL-1B juga dapat mengaktivasi limfosit sehingga mengalami proliferasi dan diferensiasi. Limfosit bisa berdiferensiasi menjadi sel T efektor dan sel plasma atau sel limfosit B sebagai penghasil antibodi. Sinyal dari interleukin-1 dapat menyebabkan sel TH17 mengalami proliferasi melalui adaptor MyD88 (J. Chang, Burkett, Borges, Kuchroo, \& Turka, 2013). Produksi interleukin 1 dapat menimbulkan beberapa kerugian seperti penyakit autoinflamasi, rheumatoid arthritis, enchepalomielitis, autoimun dan gout (El \& Tallima, 2017). Demikian juga dengan IL-6 Sitokin proinflamasi tersebut dapat menginduksi atau mempengaruhi respon dari limfosit (Moro-garcía et al., 2018). Peningkatan jumlah limfosit absolut dari partisipan $\mathrm{N}$ dan $\mathrm{P}$ mendandakan adanya inflamasi kronis akibat hiperurisemia.

Pemeriksaan cairan sendi terhadap jumlah leukosit harus dilakukan terutama jika penderita mengalami hiperurisemia asimptomatik. Dalam cairan sendi, akan terlihat adanya kristal asam urat dan adanya peningkatan jumlah leukosit, yang mengindikasikan adanya inflamasi jaringan sekitar akibat hiperurisemia yang mengkristal (Andres et al., 2017).

\section{KESIMPULAN}

Penelitian ini mendeskripsikan bahwa pada penderita hiperurisemia memiliki jumlah limfosit absolut yang meningkat sebesar 6,7\% dan jumlah limfosit absolut dalam kondisi normal yaitu sebesar 93,3\%. Pemeriksaan jumlah limfosit absolut harus tetap dilakukan agar dapat mengontrol prognosis inflamasi akut atau kronis akibat hiperurisemia, sebagai respon imun adaptive.

\section{UCAPAN TERIMAKASIH}

Peneliti mengucapkan terimakasih kepada pihak Laboratorium RS Jasa Kartini Tasikmalaya, Petugas Laboratorium Program Studi D-III Teknologi Laboratorum Medis STIKes Bakti Tunas Husada Tasikmalaya. 


\section{KONFLIK KEPENTINGAN}

Hasil penelitian dan publikasi ini tidak memiliki konflik kepentingan.

\section{REFRENSI}

Abbas, A. K., \& Licthman, A. H. (2015). Cellular and Molecular Immunology (Eighth). Philadelphia: Elsevier Saunders. https: //doi.org/10.1016/B978-07020-3369-8.00001-X

Andres, M., J.A. Bernal, \& Pascual, M. D. A. (2017). Synovial Fluid Leukocyte Count And Its Association With Crystal Deposition In Asymptomatic Hyperuricemia: A Preliminary Report. Scientific Abstracts, 18(June), 2017. https: / / doi.org/10.1136/annrheumdis-2017-eular.3258

Braga, T. T., Forni, M. F., Correa-Costa, M., Ramos, R. N., Barbuto, J. A., Branco, P., ... Camara, N. O. S. (2017). Soluble Uric Acid Activates the NLRP3 Inflammasome. Scientific Reports, 7(January), 1-14. https: / / doi.org/10.1038/srep39884

Busso, N., \& So, A. (2010). Mechanisms of Inflammation in Gout. Arthritis Research \& Therapy, (12), 206. Retrieved from http://arthritisresearch.com/content/12/2/206\%0AREVIEW

Castro-junior, A. B., Coelho, B., Gomes-santos, A. C., Pires, A., Silva, R., Santiago, D., ... Monteiro, N. (2012). Oral tolerance correlates with high levels of lymphocyte activity. Cellular Immunology, 280(2), 171-181. https: / / doi.org/10.1016/j.cellimm.2012.12.004

Chang, C.-S., Chen, T.-Y., Lu, Y.-C., Yu, T.-H., Wang, C.-P., Hung, W.-C., ... Jean, M.-Y. (2017). Associations of Peripheral Total and Differential Leukocyte Count with Features of Hyperuricmia in Chinese Male Steel Workers. E-Da Medical Journal, 4(1), 1-12.

Chang, J., Burkett, P. R., Borges, C. M., Kuchroo, V. K., \& Turka, L. A. (2013). MyD88 is essential to sustain mTOR activation necessary to promote $T$ helper 17 cell proliferation by linking IL-1 and IL-23 signaling. PNAS, 110(6), 2270-2275. https://doi.org/10.1073/pnas.1206048110/ /DCSupplemental.www.pnas.org/cgi/doi/10.1073/pnas.1206048110

Di, Y., Wang, J., Chen, Y., Sun, N., Wu, L., \& Dai, X. (2017). Elevated Interleukin $1 \mathrm{~B}$ and Interleukin 6 Levels in the Serum of Children With Hyperuricemia. Journal of Clinical Rhematology, 00(00), 1-5. https: / /doi.org/10.1097/RHU.0000000000000611

Duan, L., Luo, J., Fu, Q., Shang, K., Wei, Y., Wang, Y., ... Chen, J. (2019). 
JolMedLabS

Meri Meri, dkk | 21

Decreased Expression of CD14 in MSU-Mediated Inflammation May Be Associated with Spontaneous Remission of Acute Gout. Journal of Immunology Research, 2019, 1-7. https://doi.org/10.1155/2019/7143241

El, R., \& Tallima, H. (2017). Physiological functions and pathogenic potential of uric acid: A review. Journal of Advanced Research, 8(5), 487-493. https://doi.org/10.1016/j.jare.2017.03.003

Firestein, G. S., Budd, R. C., Gabriel, S. E., Mclnnes, I. B., \& O’Dell, J. R. (2013). Kelley's Textbook of Rheumatology (Ninth Edit). Philadelpia: Elsevier Saunders.

Frezzatti, R., Alves, P. L., Alponti, R. F., \& Silveira, P. F. (2018). Mesenchymal stem cells (MSCs) from adipose tissue in the repair of acute renal failure (ARF) induced by hyperuricemia. Cytotherapy, 20(5), S51. https://doi.org/10.1016/j.jcyt.2018.02.137

Ghaemi-oskouie, F., \& Shi, Y. (2011). The Role of Uric Acid as an Endogenous Danger Signal in Immunity and Inflammation. Curr Rhematol Rep, (13), 160166. https://doi.org/10.1007/s11926-011-0162-1

Liu, J., Shen, P., Ma, X., Yu, X., Ni, L., Hao, X., ... Chen, N. (2018). White blood cell count and the incidence of hyperuricemia : insights from a communitybased study. LETTER TO FRONTIERS OF MEDICINE White, 1-6. https://doi.org/https://doi.org/10.1007/s11684-017-0579-7 LETTER

Luo, P., Huang, Y., Xu, T., Ji, Y., Yu, N., \& He, L. (2016). Relationship between hyperuricemia and neutrophil-to-lymphocyte ratio in type 2 diabetes mellitus, 9(10), 10833-10838.

Maden, M., Pamuk, G. E., \& Pamuk, Ö. N. (2017). Development of Atherosclerotic Cardiovascular Mortality in Gouty Arthritis and Rheumatoid Arthritis Patients: Are They Associated With Mean Platelet Volume and Neutrophil-Lymphocyte Ratio? A Comparative Study, 32(1), 39-45. https://doi.org/10.5606/ArchRheumatol.2017.6033

Maiuolo, J., Oppedisano, F., Gratteri, S., Muscoli, C., \& Mollace, V. (2016). Regulation of uric acid metabolism and excretion. International Journal of Cardiology, 213, 8-14. https://doi.org/10.1016/j.ijcard.2015.08.109

Martillo, M. A., Nazzal, L., \& Crittenden, D. B. (2014). The Crystallization of Monosodium Urate. Curr Rheumatol Rep, 16(2), 1-13. https://doi.org/10.1007/s11926-013-0400-9.The

Mayer-barber, K. D., \& Yan, B. (2016). Clash of the Cytokine Titans : counterregulation of interleukin-1 and type I interferon-mediated inflammatory responses. Cellular \& Molecular Immunology, 14(1), 22-35. https://doi.org/10.1038/cmi.2016.25 
Moro-garcía, M. A., Mayo, J. C., Sainz, R. M., Alonso-arias, R., Vida, C., \& Alonso-arias, R. (2018). Influence of Inflammation in the Process of $T$ Lymphocyte Differentiation: Proliferative, Metabolic, and Oxidative Changes. Fointer in Immunology, 9(March). https://doi.org/10.3389/fimmu.2018.00339

Pamely, M. J. (2013). Medical Notes Imunologi Klinik. (H. Sutardi, Ed.). Jakarta: Karisma Publishing Group.

Ramadan, A., Land, W. G., \& Paczesny, S. (2017). Editorial: Danger signals triggering immune response and inflammation. Frontiers in Immunology, 8(AUG), 1-3. https://doi.org/10.3389/fimmu.2017.00979

Rock, K. L., Kataoka, H., \& Lai, J.-J. (2013). Uric Acid As a Danger Signal in Gout and Its Comorbidities. Nature Reviews Rheumatology, 9(1), 13-23. https://doi.org/10.1038/nrrheum.2012.143.Uric

Ruggiero, C., Cherubini, A., Ble, A., Bos, A. J. G., Maggio, M., Dixit, V. D., ... Ferrucci, L. (2006). Uric acid and inflammatory markers. European Heart Journal, (27), 1174-1181. https://doi.org/10.1093/eurheartj/ehi879

Schett, G., Schauer, C., Hoffmann, M., \& Herrmann, M. (2015). Why does the gout attack stop? A roadmap for the immune pathogenesis of gout. $\mathrm{Bmj}$, 1(Suppl 1), 1-5. https: //doi.org/10.1136/rmdopen-2015-000046

Stewart, D. J., Langlois, V., \& Noone, D. (2019). Hyperuricemia and Hypertension : Links and Risks. Integrated Blood Pressure Control, 12, 4362.

Su, P., Hong, L., Zhao, Y., Sun, H., \& Li, L. (2016). The Association Between Hyperuricemia and Hematological Indicators in a Chinese Adult Population. Medicine, 95(7), 1-6. https://doi.org/10.1097/MD.0000000000002822

Tojek, K., Banaś, W., Czerniak, B., Kowalczyk, G., Szukay, B., Korzyckawilińska, W., ... Budzyński, J. (2020). Total blood lymphocyte count as a prognostic factor among unselected inpatients. Advances in Medical Sciences, 65(1), 141-148. https://doi.org/10.1016/j.advms.2020.01.001

Wahid, S., \& Miskad, U. A. (2016). Imunologi (1st ed.). Surabaya: Brillian Internasional.

Yuan, J., Zhao, L., Luo, J., Gao, C., Shang, L., \& Li, Q. (2018). Absolute Numbers of Peripheral TH17 and TH2 Cells Increased in Patients With Gout. Bmj, 17(June), 2018. https://doi.org/10.1136/annrheumdis-2018eular.5616 